\title{
REDEMPTIONS OF STOCK UNDER THE INTERNAL REVENUE CODE OF 1954
}

\author{
Edwin S. Cohen $\dagger$
}

\section{INTRODUCTION}

The development of rules for determining whether a distribution by a corporation in exchange for part of its outstanding stock is to be treated as producing dividend income or capital gain or loss to its shareholders is a most perplexing matter. If a corporation which has earnings or profits distributes cash or other property to its shareholders without the surrender of stock by the shareholders, it is clear that they have dividend income which is subject to tax at surtax rates. It is equally clear that if the shareholders sell their stock to third parties at a profit, the selling shareholders normally ${ }^{1}$ realize capital gain even though the difference between the sales price and their cost for their stock is due solely to accumulated earnings in the corporation. But where the shareholder sells his stock back to the issuing corporation rather than to third parties, there may be difficulty in determining whether as a practical matter the surrender of the shares is a meaningless gesture or whether it is of such significance as to warrant treating the proceeds from the corporation as though they had been received on a sale to third parties.

The Old Law.-The 1939 Code provided in Section 115(c) that "amounts distributed in partial liquidation of a corporation shall be treated as in part or full payment in exchange for the stock." In Section 115(i) the phrase "amounts received in partial liquidation" was defined to mean "a distribution by a corporation in complete cancellation or redemption of a part of its stock, or one of a series of distributions in complete cancellation or redemption of all or a portion of its stock." It was then provided in Section $115(\mathrm{~g})$ that "If a corporation cancels or redeems its stock . . . at such time and in

$\dagger$ Member of the Virginia and New York Bars. B.A., Richmond, 1933; LL.B., Virginia, 1936.

1. Of course the profit would be ordinary income if the sellers are dealers in the stock, or if the stock is that of a collapsible corporation. See INT. REv. CoDE oF 1954, §341. See also \$306. Except where otherwise specified, the statutory references below are to the Internal Revenue Code of 1954. 
such manner as to make the distribution and cancellation or redemption in whole or in part essentially equivalent to the distribution of a taxable dividend," the amount so distributed would be treated as a taxable dividend to the extent it represents a distribution of earnings or profits accumulated after February 28, 1913.

The Treasury Regulations under Section 115(g) of the 1939 Code were relatively brief. After stating that the question whether a distribution in connection with a cancellation or redemption of stock is essentially equivalent to the distribution of a taxable dividend depends upon the circumstances of each case, the Regulations made two pronouncements: (1) a redemption by a corporation of a portion of its stock "pro rata among all the shareholders will generally be considered as effecting a distribution essentially equivalent to a dividend distribution" to the extent of the accumulated earnings; and (2) a redemption by a corporation of all of the stock of a particular shareholder, "so that the shareholder ceases to be interested in the affairs of the corporation," does not effect a distribution of a taxable dividend. Then, after ruling out cases of complete liquidation, the Regulations provided that "in all other cases the facts and circumstances should be reported to the Commissioner for his determination whether the distribution, or any part thereof, is essentially equivalent to the distribution of a taxable dividend." 2

The New Law.-The 1954 Code has attempted to separate the area formerly designated as "partial liquidations" into two categories, the first of which is loosely referred to as "stock redemptions" and the other as "partial liquidations." According to the Senate Finance Committee Report, ${ }^{3}$ the new Code "separates into their significant elements the kind of transaction now incoherently aggregated in the definition of a partial liquidation. . . . Those distributions which may have capital-gain characteristics because they are not made pro rata among the various shareholders" are dealt with in Section 302 and other related provisions in Part I of Subchapter C. "On the other hand, those distributions characterized by what happens solely at the corporate level by reason of the assets distributed would be included as within the concept of a partial liquidation," and are dealt with in Part II relating to corporate liquidations. The phrase "partial liquidation" is defined in Section 346 in terms apparently intended by the draftsmen to identify it with the contraction of the corporate business.

Whether this attempted dichotomy has produced more or less confusion appears somewhat problematical. Its principal practical

2. U.S. Treas. Reg. 118, $\$ 39.115$ (g)-1 (a) (2) (1953).

3. Sen. ReP. No. 1622, 83d Cong., 2d Sess. 49 (1954) (hereinafter Sen. Rep.). 
significance seems to lie in the method of application of Section 311, dealing with the taxability of corporations on distribution to stockholders of appreciated property. ${ }^{4}$ Section 311 states broadly that no gain or loss shall be recognized to a corporation on the distribution of its stock or property, except with respect to (a) certain installment obligations, (b) LIFO inventory or (c) property subject to a liability in excess of its basis. Section 336 also states broadly that except with respect to certain installment obligations, no gain or loss shall be recognized to a corporation on the distribution of property in partial liquidation. Neither section in the statute or the proposed Regulations refers to the other; but the apparent intention is that gain will be recognized to a corporation on a distribution of LIFO inventory or property subject to a liability in excess of basis if the distribution fails to qualify as a partial liquidation under Section 346, even though it qualifies for capital gain treatment to the shareholder under Section 302.

If this is the principal effect of redefining "partial liquidations," it may well be asked whether the result could not have been accomplished in more direct fashion in Section 311 itself. The attempt to have this frequently used phrase mean one thing under the old Code and a wholly different thing under the new Code produces a certain amount of confusion. For example, there is apparently a hiatus in the law with respect to the basis to shareholders of property distributed in redemption of stock under Section 302 which does not qualify as a partial liquidation under Section $346 .^{5}$ Neither Section 301(d) (relating to the basis of property received in a distribution not covered by other sections, such as Section 302) nor Section 334(a) (relating to the basis of property received in a partial liquidation) would seem to cover the case.

Even in Section 346 itself the strict differentiation between stock redemptions and partial liquidations had to be relaxed in part when the bill was in conference in order to make clear that the provisions of the Code relating to information returns $(\$ 6043)$ and relating to divi-

4. It also has significance in the case of redemptions of "section 306 stock" (e.g., preferred stock issued as a tax-free dividend on common stock). Such stock may be redeemed at capital gain rates in a "partial liquidation" under \$346 even though redemption under $\S 302$ might by virtue of the provisions of $\S 306$ result in ordinary income to the shareholder. See note 82 inffra. Further it should be noted that the "constructive stock ownership" rules of $\S 318$ do not apply under $\S 346$.

5. Under the 1939 Code there was no provision specifically relating to the basis to shareholders of property distributed in kind either in partial liquidation or in other stock redemptions. The general provision of Int. Rev. Code of 1939, §113, as amended, 67 STAT. 616, 618 (1953), that basis would be cost was considered applicable, however, and the cost was deemed to be the fair market value of the property distributed in redemption at the time of distribution. 
dends paid deduction ( $\$ 562(\mathrm{~b})$ ) applied to stock redemptions. Section 346(a) states that for the purposes of those latter provisions the term "partial liquidation" includes stock redemptions to which Section 302 applies. ${ }^{6}$

Section 346 (c) provides that the fact that a distribution qualifies as a capital gain or loss transaction under Section 302 shall not be taken into account in determining whether the distribution constitutes a distribution in partial liquidation. The proposed Regulations provide that Section 302 is not applicable to distributions in complete liquidation nor to that portion of any distribution which qualifies as a partial liquidation under Section 346. ${ }^{7}$ The proposed Regulations also state that if a distribution qualifies under both Section 302 and Section 346, only Section 346 shall be applicable and none of the limitations of Section 302 shall apply. ${ }^{8}$ This would indicate that where a corporation terminates one of its businesses in a manner qualifying under Section 346 and uses the proceeds to redeem part of its outstanding stock, the distribution will result only in capital gain or loss to the shareholders whether or not it is made pro rata among them.

\section{Section 302: Distributions in Redemption of Stock}

Section 302(a) of the new law provides that if a corporation redeems its stock in any one of four types of transactions described in Section 302(b), the redemption shall be treated as a distribution in part or full payment in exchange for the stock. The four categories are as follows:

(1) a redemption which "is not essentially equivalent to a dividend";

(2) a distribution which is "substantially disproportionate with respect to the shareholder";

6. Section $312(\mathrm{e})$, dealing with earnings and profits, specifically refers both to partial liquidations and stock redemptions under $\$ 302$ in stating that the part of either distribution which is properly chargeable to capital account shall not be treated as a distribution of earnings and profits. Query whether the failure of $\$ 341$ (a) to refer to stock redemptions under $\$ 302$ creates a loophole in the collapsible corporation provisions.

7. The Senate Finance Committee Report states that where a partial liquidation occurs, but an amount in excess of the amount permitted to be distributed in such liquidation is distributed, the excess shall be treated as if received in the redemption to which $\S 302$ applies. SEN. REP. 233. The proposed Regulations do not contain this precise statement. They state, in somewhat different terms, that if a corporation makes a distribution which qualifies as a partial liquidation and at the same time redeems additional stock which does not meet the requirements of $\$ 346$, then $\$ 302$ shall apply to that portion of the distribution which does not qualify under $\$ 346$. U.S. Treas. Proposed Reg. §1.302-1, 19 FED. REG. 8239 (1954).

8. U.S. Treas. Proposed Reg. §§ 1.302-1, 1.346-2, 19 FED. REg. 8239, 8268 (1954). 
(3) a distribution which is "in complete redemption of all of the stock of the corporation owned by the shareholder"; and

(4) a distribution which is in redemption of stock issued by a railroad corporation pursuant to a plan of reorganization under Section 77 of the Bankruptcy Act.

Section 302(d) then provides that except as otherwise provided in Subchapter C (such as in the partial liquidation sections), any redemption not qualifying within one of these four categories shall be treated as a distribution of property under Section 301-the general provision relating to dividends and distributions in excess of earnings.

\section{Redemptions Not Essentially Equivalent to Dividends- Section 302(b) (1)}

In the House bill, an attempt was made to eliminate the general language of Section $115(\mathrm{~g})$ of the 1939 Code regarding essential equivalence to a dividend and to prescribe instead a series of definite rules for determining the situations in which redemptions of stock not in partial or complete liquidation give rise to capital gain or loss to the shareholder. ${ }^{9}$ The Senate Finance Committee Report stated that the rules in the House bill "appeared unnecessarily restrictive, particularly, in the case of redemptions of preferred stock which might be called by the corporation without the shareholder having any control over when the redemption may take place." 10 The Report notes that, accordingly, the Committee "follows existing law by reinserting the general language indicating that a redemption shall be treated as a distribution in part or full payment in exchange for stock if the redemption is not essentially equivalent to a dividend." 11 The Report further stated:

"In general, under this subsection your committee intends to incorporate into the bill existing law as to whether or not a reduction [sic] is essentially equivalent to a dividend under section $115(\mathrm{~g})(1)$ of the $1939 \mathrm{Code}$, and in addition to provide three definite standards in order to provide certainty in specific instances." 12

9. H.R. 8300 , 83d Cong., 2d Sess. $\$ 302$ (1954).

10. SEN. REP. 44.

11. SEN. ReP. 44-45. The Report also states: "Unlike the House bill, however, section 302 does not provide specific statutory guides governing the tax consequences of every stock redemption. In lieu of the approach in the House bill, your committee intends to revert in part to existing law by making the determination of whether a redemption is taxable as a sale at capital gains rates or as a dividend at ordinary income rates dependent, except where it is specifically provided otherwise, upon a factual inquiry." Id. at 233.

12. SEN. ReP. 233. 
The new statute eliminates the old words of Section $115(\mathrm{~g})$ "at such time and in such manner," but the quoted excerpt from the Senate Report indicates that no change in result was intended.

The new Section 302(b) (5) provides that the fact that the redemption fails to meet the specific requirements of Section 302(b) (2), (3) and (4) "shall not be taken into account" in determining whether the redemption is not essentially equivalent to a dividend under Section 302 (b) (1). The proposed Regulations restate this rule in somewhat different language by providing that "if a distribution is determined to be not essentially equivalent to a dividend, it is immaterial that it does not meet the requirements" of the three specific provisions. ${ }^{13}$ Literally, this wording is not as clear from the taxpayer's standpoint as the statute, but it is unlikely that any different result is intended in view of the specific provision in the statute itself.

Deficit Corporations.- The proposed Regulations take the position, as did the Senate Finance Committee Report, ${ }^{14}$ that a deficit corporation may make a distribution essentially equivalent to a dividend. The proposed Regulations state:

"The determination of whether or not a distribution is essentially equivalent to a dividend shall be made without regard to the earnings and profits of the corporation at the time of the distribution. For example, if A owns all the stock of a corporation and the corporation redeems part of his stock at a time when it has no earnings and profits, the distribution shall be treated as a distribution under Section 301." 15

Since a distribution by a deficit corporation not in redemption of stock would not be a "dividend" because of the absence of earnings and profits, a purist might consider it anomalous to regard a distribution by the deficit corporation in redemption of stock as being equivalent to a dividend; the distribution would seem to be equivalent to a distribution which would not be a dividend. If this is a correct analysis, then by virtue of Section 302(b) (1) and Section 302(a) the amount received is treated as a distribution in full payment for the stock redeemed, is taxed as a capital gain under Section 302 and never reaches the ambit of Section 301.

13. U.S. Treas. Proposed Reg. §1.302-2(a), 19 FED. Reg. 8239 (1954).

14. The Report stated: "For this purpose the presence or absence of earnings and profits of the corporation is not material. Example: $X$, the sole shareholder of a corporation having no earnings or profits causes the corporation to redeem half of its stock. Paragraph (1) does not apply to such redemption notwithstanding the absence of earnings and profits. The fact that the proceeds of the redemption are not taxable as ordinary income to $X$ results through application of section 302 (d) and section 301." SEN. REP. 234.

15. U.S. Treas. Proposed Reg. §1.302-2(a), 19 Fed. Reg. 8239 (1954). 
The reason for the contrary conclusion in the proposed Regulations and the Committee Report appears to be that in the House bill a distribution in redemption of stock was treated as made in payment for stock only if it met certain specific tests regarding substantially disproportionate redemptions or complete termination of the stockholder's interest; it was immaterial whether or not the distribution was otherwise "not essentially equivalent to a dividend." Under the House bill, then, if the distribution did not fit the specific tests of Section 302 , it was "treated as a distribution of property as provided in Section 301"; and this result followed whether the corporation had a surplus or a deficit. The conclusion of the Regulations and the Committee Report was, therefore, proper under the House bill.

However, when the Senate inserted Section 302(b) (1) to state that even if the specific statutory tests of Section 302(b) were not met, capital gain or loss treatment would still be given if the distribution is "not essentially equivalent to a dividend," the previous interrelationship of the various provisions seems to have been broken. If a deficit corporation cannot make a distribution in redemption of stock essentially equivalent to a "dividend," then such a distribution automatically becomes subject only to the capital gain or loss provisions of Section 302(a) and does not qualify under Section 302(d) to be fed over to Section 301.

Despite this technical difficulty in the final version of the bill, the result sought to be accomplished would seem to be basically proper; the phrase "essentially equivalent to a dividend" probably should be changed in the statute to read "essentially equivalent to a distribution not in redemption of stock."

Whether a distribution by a deficit corporation can be essentially equivalent to a dividend can have practical consequences. For example, even though the amount received would not be taxed as ordinary income because of the absence of earnings and profits, it would, under Section 301 (c), be applied against the basis of the stock in the hands of the shareholders until the basis is exhausted, the balance being treated as capital gain. However, if the distribution is not regarded as essentially equivalent to a taxable dividend, the difference between the amount distributed and the basis to the shareholder of the particular shares redeemed would be treated as a capital gain or loss regardless of the basis of the remaining shares not redeemed. Furthermore, in the case of a corporate shareholder receiving property in redemption of stock of another corporation, the basis of the property in the hands of the other corporation would carry over to the stockholder corporation if the distribution were essentially equivalent 
to a dividend; but if it were not equivalent to a dividend, apparently the basis would be the fair market value of the property at the time of distribution. ${ }^{16}$

Essential Equivalence.-The proposed Regulations provide, in language similar to the old Regulations, that

"All distributions in pro rata redemption of a part of the stock of a corporation will ordinarily be treated as distributions under section 301 if the corporation has only one class of stock outstanding. . . . The redemption of all of one class of stock (except section 306 stock), either at one time or in a series of redemptions, will ordinarily be considered a distribution under section 301 if all classes of stock outstanding at the time of the redemption are held in the same proportion." 17

The Regulations then add that "This rule shall apply regardless of the provisions of the stock certificate and regardless of whether all stock being redeemed was acquired by the stockholders from whom the stock was redeemed by purchase or otherwise." The latter statement incorporates in the Regulations a rule established in a number of court decisions that where shareholders purchase stock from third parties and then have the newly purchased stock redeemed by the corporation, the transaction may be treated as to them as a distribution essentially equivalent to a dividend, even though the shareholders would have had no dividend had the corporation purchased the stock directly from the third parties. ${ }^{18}$

Aside from these comments as to pro rata redemptions the Regulations provide no further aid on the general subject of essential equivalence to a dividend. They provide merely that in all other instances (except those dealt with in Section 302(b) (2), (3) and (4)) the question "depends upon the circumstances of each case" and state, as did the old Regulations, that in such cases "the facts and circumstances should be reported to the Commissioner for his determination." They do provide, however, as discussed further below, ${ }^{19}$ that in determining whether a redemption is essentially equivalent to a dividend, the "attribution" or "constructive stock ownership" rules of Section 318 are applicable.

16. $\$ 301(\mathrm{~d})(2)$. But see discussion in text at p. 741 supra, regarding the basis of property distributed in redemption of stock.

17. U.S. Treas. Proposed Reg. §1.302-2(b), 19 FED. REG. 8239 (1954).

18. E.g., Wall v. United States, 164 F.2d 462 (4th Cir. 1947) ; cf. Zenz v. Quinlivan, 213 F.2d 914 (6th Cir. 1954); Ray Edenfield, 19 T.C. 13 (1952), acq., 1953-1 Cum. Bulr. 4.

19. See, text at note 53 infra. 


\section{Substantially Disproportionate Stock Redemptions-}

Section 302(b)(2)

Under Section 302(b)(2) a redemption will not be regarded as a dividend if the following requirements are met:

(1) immediately after the redemption the shareholder must own less than $50 \%$ of the total combined voting power of all classes of stock entitled to vote; ${ }^{20}$

(2) the ratio which the voting stock owned by the shareholder immediately after the redemption bears to the entire voting stock $^{21}$ outstanding at such time is less than $80 \%$ of

the ratio which the voting stock owned by the shareholder immediately before the redemption bears to the entire voting stock outstanding at such time; and

(3) the ratio which the common stock owned by the shareholder immediately after the redemption bears to all the entire common stock of the corporation

\section{is less than $80 \%$ of}

the ratio which the common stock owned by the shareholder immediately before the redemption bears to the entire common stock outstanding at such time. ${ }^{22}$

To illustrate the operation of these provisions, assume that $A$ owns $60 \%$ of the sole class of outstanding stock of a corporation. Following the redemption of part of his stock he owns only $40 \%$ of the remaining outstanding stock. The redemption will not be treated as a dividend because after the redemption $A$ owns less than $50 \%$ of the voting power, and the percentage of voting stock and common stock which he owns after the redemption (40\%) is less than $80 \%$ of the percentage which he owned prior to the redemption $(60 \%)$.

20. If the second and third requirements are met, the distribution is regarded as "substantially disproportionate." But even so, $\$ 302$ (b) (2) will not apply to give the distribution capital gain or loss treatment unless the first requirement-that the shareholder after the redemption have less than $50 \%$ of the voting power-is also met.

21. Where there are two or more classes of voting stock, neither the statute nor the proposed Regulations make clear whether the ratio is to be determined by reference to total combined voting power or fair market value. For purposes of determining whether the shareholder has less than a 50\% interest in the corporation after the redemption, $\$ 302$ (b) (2) (B) refers to total combined voting power; for purposes of determining the reduction in ratio of common stock holdings where there are two or more classes of common stock, $\$ 302(\mathrm{~b})(2)(\mathrm{C})$ uses the test of fair market value. Presumably where the determination relates to reduction in ratio of voting stock owned, the test should be based upon total combined voting power.

22. $\$ 302(\mathrm{~b})(2)(\mathrm{C})$. For this purpose common stock includes both voting and non-voting stock. 
Again, assume that $B$ owns $90 \%$ of the sole class of outstanding stock prior to the redemption and $60 \%$ after the redemption. $B$ complies with the requirement that his percentage ownership after redemption be less than $80 \%$ of that existing prior to the redemption, but he cannot meet the specific requirements of Section 302(b) (2) since after the redemption he still possesses more than $50 \%$ of the voting power in the corporation.

Assume that $C$ owns $5 \%$ of the sole class of outstanding stock of the corporation prior to the redemption of part of his stock and $4 \%$ after the redemption. Although $C$ complies with the requirement that he own less than $50 \%$ of the voting power after the redemption, Section 302(b) (2) will not be applicable because the $4 \%$ interest which he has after redemption is not less than $80 \%$ of the $5 \%$ interest he had prior to the redemption.

Though in the latter two illustrations $B$ and $C$ do not satisfy the specific requirements of Section 302(b) (2), they would still be entitled to capital gain treatment if under Section 302(b) (1) the redemption were treated as not essentially equivalent to a dividend.

There is an interesting mathematical point which must be watched in determining whether the $80 \%$ test has been met. It is not sufficient that the shareholder reduce the number of his shares to less than $80 \%$ of those he formerly owned; he must reduce his percentage ownership below $80 \%$ of his previous percentage ownership. In the process of redemption the total number of outstanding shares will be reduced. Failure to note this latter fact caused the Senate Finance Committee Report to fall into error in two illustrations. ${ }^{23}$ Thus the Report states that "if an individual, A, owns 50 of the 100 outstanding shares of the stock of a corporation and 11 shares are redeemed by the corporation from him the amount received would be treated as if received in connection with a disproportionate redemption." 24 To qualify as a disproportionate redemption $A$ would have to reduce his percentage ownership below $40 \%$ (i.e., $80 \%$ of his original $50 \%$ ownership). Because of the redemption of 11 shares, the total outstanding shares would be reduced from 100 to 89 . Owning 39 out of the remaining 89 shares, or $43.8 \%$ of the outstanding stock, $A$ would not have reduced his percentage ownership below $40 \%$. In reality, to go below $40 \%$ of the remaining outstanding stock, there would have to be redeemed from $A 17$ shares instead of the 11 shares mentioned in the Committee Report.

23. Sen. Rep. 234, 253.

24. SEN. REP. 253. 
Redemption of Non-Voting Stock.-The proposed Regulations take the position that "Section 302(b) (2) applies only to the redemption of voting stock or common stock, or both." 25 They then continue by stating:

"However, if a redemption is treated as an exchange to a particular shareholder under the terms of section 302(b) (2), the simultaneous redemption of nonvoting preferred stock (which is not section 306 stock) owned by such shareholder is similarly treated as an exchange."

While the result reached in these sentences in the Regulations appears to be correct, the statute does not seem to be written in this fashion. The statute states that a redemption shall be treated as a distribution in exchange for the stock if it is "substantially disproportionate"; it then states that the distribution is "substantially disproportionate" if the ratio of voting stock and of common stock owned by the shareholder after the redemption is less than $80 \%$ of the similar ratios prior to redemption. If the required reductions in percentage of voting stock and common stock ownership occur at the time of the distribution, the statute states that "the distribution" shall be treated as in exchange for stock. "The distribution" would seem to mean the entire distribution, including that made in respect of non-voting preferred stock, and not merely that part of the distribution which is made with respect to the voting stock or the common stock. The proposed Regulations appear to take the position, however, that the simultaneous redemption of non-voting preferred stock will be given capital gain treatment not because of the specific provisions of Section 302(b)(2) but because they will be treated under 302 (b) (1) as not essentially equivalent to a dividend.

In any event it seems to be clear both under the statute and under the proposed Regulations that if the shareholder owns both non-voting preferred stock and common stock and desires to have a redemption of the preferred stock come under the specific protection of the Regulations, there must be simultaneously redeemed enough of his common stock so that thereafter he owns less than $50 \%$ of the total common stock outstanding and his percentage ownership of common stock is reduced below $80 \%$ of what it was before the redemption of the preferred stock occurred. But what if at the time of the redemption of the non-voting preferred stock, the shareholder effects the necessary reduction in his ownership of voting stock and common stock by making

25. U.S. Treas. Proposed Reg. §1.302-3(a), 19 FED. REg. 8240 (1954). 
a simultaneous sale of voting common to third parties instead of having it redeemed by the corporation? Under the statute it would appear, at least as a literal matter, that a sale to third parties of the necessary amount of voting common stock would serve to make Section 302(b) (2) applicable if it occurred simultaneously with the redemption of the non-voting preferred stock, since the common stock ownership existing "immediately after the redemption" would be less than $80 \%$ of that existing "immediately before the redemption." The same situation would exist if the reduction in percentage of common stock or voting stock occurred by reason of a new issuance of additional voting common stock by the corporation to third parties simultaneously with the redemption of the non-voting preferred stock. The approach taken in the proposed Regulations leaves the application of Section 302(b) (2) to such transactions in considerable doubt.

What if the shareholder owns no voting stock before the redemption of his non-voting preferred or common stock? Technically he may be unable to comply with the statutory requirement that he reduce his percentage ownership of voting stock to less than $80 \%$ of that existing before the redemption of his non-voting stock, since it was zero at both times. But obviously he has complied with the intendment of the law. The Regulations should say explicitly that the requirement of more than $20 \%$ reduction in voting stock ownership under Section 302(b) (2) is fulfilled if the shareholder owns no such stock immediately before or after redemption. A similar statement should be made regarding the absence of common stock ownership before and after redemption. This would then make clear that the redemption of non-voting preferred stock is to be accorded capital gain or loss treatment where the shareholder owns no voting or common stock, either actually or constructively; and similarly that the redemption of voting preferred stock is to have the same effect if more than $20 \%$ of such preferred stock is redeemed from the shareholder and he owns no common stock before or after the redemption.

Simultaneous Redemption from Several Stockholders.-Where stock is redeemed in disproportionate amounts from several stockholders simultaneously, the proposed Regulations state that "the requirements under section 302(b) (2) shall be applied to each shareholder separately." 26 In such case the distribution might be treated as a capital gain to one shareholder and a dividend to the other. The Regulations contain the following example: 


\section{Shares Owned Before \\ After}

Stockholder Redemption Redemption

$A$
$B$
$C$
$D$

Total

\begin{tabular}{|c|c|}
\hline 100 & 45 \\
\hline 100 & 75 \\
\hline 100 & 80 \\
\hline 100 & 100 \\
\hline
\end{tabular}

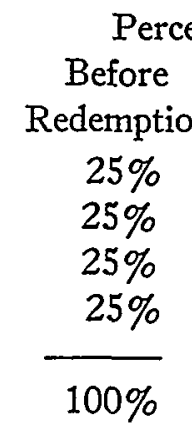

Percentage Owned

After

Redemption

The Regulations conclude that the redemption is disproportionate with respect to $A$ since his percentage ownership after the redemption (15\%) is less than $80 \%$ of that before the redemption (25\%); but it is not disproportionate with respect to $B$ and $C$ since their percentage ownership remains the same or rises.

Series of Redemptions.-The statute contains in Section 302(b) (2) (D) a statement that the paragraph shall not apply to any redemption "made pursuant to a plan the purpose or effect of which is a series of redemptions resulting in a distribution which (in the aggregate) is not substantially disproportionate with respect to the shareholder." This is designed to cover the situation, for example, where a corporation having two equal shareholders redeems in 1954 a substantial proportion of the stock owned by one shareholder and in 1955 redeems a similar amount of stock owned by the other shareholder, thus reestablishing the equal ownership of the stock. The Regulations restate this rule with the comment only that "Whether or not such a plan exists will be determined from all the facts and circumstances." 27

The statutory language does not literally apply where the old percentage ownership is reestablished by a sale of stock by one shareholder to the other following the redemption; but if the two steps occur pursuant to a single plan worked out in advance of the redemption, it is likely that a court would invoke the step transaction doctrine despite the failure of the statute to deal with this particular situation.

\section{Termination of Shareholder's Interest- Section 302(b)(3) and (c)(2)}

A complete termination of the shareholder's interest in the corporation would, in normal terms, necessarily involve a substantially disproportionate redemption under Section 302(b)(2). However, 
Section 302 (c) (1) makes the various "attribution" or "constructive stock ownership" rules of Section 318 applicable in determining the qualification of the redemption as substantially disproportionate. One of the attribution rules of Section 318 is that an individual shall be considered as owning the stock owned by his spouse, his children, his grandchildren and his parents. ${ }^{28}$ Though the redemption might not qualify as substantially disproportionate under Section 302(b) (2) because of the family attribution rules, it might still be entitled to capital gain treatment under Section 302(b) (3), which applies to cases of "complete redemption of all of the stock of the corporation owned by the shareholder." Section 302 (c) (2) provides that in determining whether under Section 302(b) (3) a distribution is in complete redemption of all of the stock owned by the shareholder, the family attribution rules shall not be applicable if certain prescribed conditions are met. These conditions may be briefly summarized as follows:

(1) immediately after the distribution the taxpayer must have no interest in the corporation (including an interest as officer, director, or employee), other than an interest as a creditor; ${ }^{29}$

(2) the taxpayer must not acquire any such interest (other than stock acquired by bequest or inheritance) within ten years from the date of the distribution; ${ }^{30}$

(3) the taxpayer must file an agreement (a) to notify the Secretary of the Treasury or his delegate of any acquisition within the next ten years of an interest described above and (b) to retain necessary records; ${ }^{31}$ and

(4) within the ten-year period prior to the distribution

(a) none of the stock redeemed was acquired, directly or indirectly, by the taxpayer from a person who at the time of redemption would be within the family attribution group, unless the acquisition did not have as one of its principal purposes the avoidance of federal income tax; ${ }^{32}$ and

(b) no person within the family attribution group acquired, directly or indirectly, from the taxpayer stock which he still owns at the time of the redemption, unless such stock so acquired from the taxpayer is redeemed in the same transaction or unless the disposition of such stock by the taxpayer to such person did not have as one of its principal purposes the avoidance of federal income tax. ${ }^{33}$

28. $\S 318(a)(1)$. See detailed discussion of this provision at pp. 760-61 infra.

29. $\$ 302(\mathrm{c})(2)(\mathrm{A})(\mathrm{i})$.

30. $\$ 302(\mathrm{c})(2)(\mathrm{A})(\mathrm{ii})$.

31. $\$ 302$ (c) (2) (A) (iii).

32. $\$ 302(\mathrm{c})(2)(\mathrm{B})(\mathrm{i})$.

33. $\S 302(\mathrm{c})(2)(B)(\mathrm{ii})$. 
Creditor Status. - In order to make this provision applicable, the shareholder must discontinue any position which he may have with the corporation as an officer, director or employee. He may, however, remain as a creditor. This latter privilege may be of substantial importance if the corporation is unable to pay cash in full for his stock interest but must give notes or other obligations for part of the redemption price. The proposed Regulations state that for this purpose a person will be considered to be a creditor "only if the rights of such person with respect to the corporation are not greater or broader in scope than otherwise necessary for the enforcement of his claim." 34 His interest must "not in any sense" be "that of a proprietor." 35 The Regulations continue:

"Thus, if the corporation may discharge its obligation to a person by payments, the amount, regularity, or certainty of which are dependent upon the earnings of the corporation, such a person is not a creditor of the corporation within the meaning of section 302 (c) (2) (A) (i)."

Bearing in mind that the "complete termination" rules are of significance only in cases where stock is owned by other close relatives, there appears to be adequate justification for this provision insofar as it relates to payments which depend in "amount" or "certainty" on earnings of the corporation, at least insofar as payments of principal are concerned. But the denial of creditor status where the "regularity" of the payments is dependent upon earnings rests on dubious ground. For example, a shareholder might have all of his interest redeemed in exchange for ten-year notes in which the amount of the principal and interest is fixed and certain, but for his greater protection as a noteholder a sinking fund arrangement might be included which might depend for its operation upon the earnings of the corporation. There would seem to be no sufficient reason why a sinking fund geared to earnings and related only to acceleration of payment should require forfeiture of creditor status if the amount of interest and principal is not dependent upon earnings.

A strict interpretation of the statute would prohibit a shareholder who has all of his shares redeemed in exchange for notes from being a director even though he acts as such only to protect his creditor position so long as the notes are outstanding. The proposed Regulations do not indicate whether it would be permissible for the notes to provide that so long as they are outstanding the holder shall be

34. U.S. Treas. Proposed Reg. §1.302-4(d), 19 FED. REg. 8240 (1954).

35. Ibid. 
entitled to have someone other than himself elected as a director to protect his creditor interest.

Prohibited Reacquisition of Interests.-The proposed Regulations provide that:

"In the case of a distributee to whom section $302(\mathrm{~b})(3)$ is applicable, who is a creditor after such transaction, the acquisition of the assets of the corporation in the enforcement of the rights of such creditor shall not be considered an acquisition of an interest in the corporation for purposes of section 302 (c) (2) unless stock of the corporation, its parent corporation, or, in the case of a redemption of stock of a parent corporation, of a subsidiary of such corporation is acquired." 36

The exception for the reacquisition of stock of a subsidiary corporation seems somewhat strange. The mere fact that on foreclosure of the notes the former shareholder would take over the corporate assets which might include, among other items, stock of a subsidiary corporation, should not prevent the application of the complete termination rules, especially where the subsidiary might be of insignificant value.

The proposed Regulations prohibit the acquisition within the succeeding ten years of an interest "in a corporation which is in any way a successor corporation to the corporation the interest in which has been terminated." ${ }^{37}$ As applied to a situation in which the business has been merely reincorporated by the same shareholders in another corporate entity, this provision seems appropriate. But the Regulation appears to be too broad in its terms; it would apply literally, for example, if the remaining shareholders within the next ten years sold the corporate assets to General Motors and the withdrawing shareholder happened to own a few shares of General Motors common stock.

It will be noted that the statute contains an exception for a reacquisition of an interest which consists of stock acquired by "bequest or inheritance." Acquisition by virtue of a gift or the termination of an inter vivos trust would be prohibited. Further, although stock might be inherited by a widow from her husband without disqualifying a redemption of stock previously made from the widow during her husband's lifetime, the widow could not, following her inheritance, become a director or officer of the corporation to protect her newly acquired interest within ten years after the redemption without destroying the protection of Section 302(c)(3). Presumably, however, she could have a representative on the board of directors.

36. U.S. Treas. Proposed Reg. $\S 1.302-4$ (e), 19 FEd. REg. 8240 (1954).

37. U.S. Treas. Proposed Reg. $\$ 1.302-4$ (c), 19 FED. Reg. 8240 (1954). 
The Taxpayer's "Agreement."-The proposed Regulations relating to the agreement which must be filed by the shareholder are quite brief. $^{38}$ The taxpayer must agree to notify the District Director of Internal Revenue for the district in which the return for the year of distribution is filed of any acquisition of an interest in the corporation within thirty days after such acquisition. The agreement must be filed with the return for the year in which the distribution occurs. The taxpayer must retain copies of the income tax returns and any other records indicating fully the amount of tax which would have been payable had the redemption been treated as a dividend. ${ }^{39}$ The statute provides that if the taxpayer acquires a prohibited interest within the ten-year period, the period of limitation on the assessment of tax for the year of distribution shall remain open for one year immediately following the date on which the taxpayer notifies the Secretary of such acquisition. Thus an innocent technical violation of the reacquisition rules at any time within ten years not only could reopen the tax for the year of distribution, but could also result in the complete elimination of the statute of limitations for the year of distribution because of the failure of the shareholder to notify the Treasury. of the reacquisition.

Transfers of Stock in the Ten Years Preceding Redemption.Peculiarly, the Regulations contain not a word with reference to the prohibitions of Section 302(c)(2)(B) concerning transfers within the family attribution group during ten years prior to the redemption date. The statute provides, among other things, that those prohibitions shall not apply if the prohibited transaction "did not have as one of its principal purposes the avoidance of Federal income tax." The Senate Finance Committee Report states that such a transfer of stock "shall not be deemed to have as one of its principal purposes the avoidance of Federal income tax merely because the transferee is in a lower income tax bracket than the transferor." 40 The purpose of the statutory prohibition is obviously to prevent a person from transferring a part of his stock holdings to a close relative and then by virtue of this split of ownership qualify the redemption of the transferor's stock or the transferee's stock as a "complete termination" of interest in the corporation. The rule is an extension of the step transaction doctrine. But unless punishment for tax reduction by intra-family transfers is intended, mere differences in surtax brackets of transferor and transferee should be immaterial for this particular purpose. The Regulations should, it is submitted, incorporate the statement of the

38. U.S. Treas. Proposed Reg. $\$ 1.302-4$ (a), 19 FED. REg. 8240 (1954).

39. U.S. Treas. Proposed Reg. $\$ 1.302-4$ (b), 19 FED. REG. 8240 (1954).

40. SEN. REP. 237. 
Committee Report or else its mere omission may give rise to an inference of its repudiation by the Treasury. ${ }^{41}$

It will be noted that while the family attribution rules of Section 318 (a) (1) are rendered inapplicable if there is a complete termination of the shareholder's interest, the remainder of the attribution rules relating to shares owned by partnerships, corporations, estates or trusts in which the shareholder is interested nevertheless apply to the same extent as in the case of substantially disproportionate distributions.

\section{Basis Adjustments}

For many years attention has been drawn to the fact that neither the Code nor the Regulations prescribed any adjustment to be made to the basis of the remaining stock held by the taxpayer where a distribution in redemption of part of his stock has been taxed as a dividend. The 1954 Code contains no such provision. But the proposed Regulations have at long last sought to cover the point. This is a matter which has many complex ramifications, particularly where constructive ownership. of stock under Section 318 is involved.

The proposed Regulations state:

"In any case in which an amount received in redemption of stock is treated as a distribution of a dividend, proper adjustment of the basis of the remaining stock will be made with respect to the stock redeemed." 42

While this sentence is quite general, it is a step forward to have recognition of the principle incorporated in the Regulations. Two brief illustrations are given in the proposed Regulations:

(1) $A$ purchases stock of Corporation $X$ for $\$ 100,000$. Half of his stock is redeemed for $\$ 150,000$, which amount is taxed as a dividend. The remaining stock held by $A$ has a basis of $\$ 100,000$.

(2) $H$ purchases all the stock of Corporation $X$ for $\$ 100,000$ and gives one-half the stock to $W$, his wife, in 1950. All of $H^{\prime}$ 's stock is redeemed in 1955 for $\$ 150,000$, and it is determined that the distribution constitutes a dividend. Immediately after the transaction, $W$ 's stock has a cost to her of $\$ 100,000$.

41. Because of the ten-year "look-back" rule it may sometimes be advisable on the organization of a family corporation to have several members of the family subscribe for stock on original issue from the corporation. If the stock is acquired from the corporation and not by purchase or gift from another closely related stockholder, it could later be redeemed within ten years at capital gain rates without raising the question whether the acquisition occurred primarily for tax avoidance purposes.

42. U.S. Treas. Proposed Reg. $\$ 1.302-2(c), 19$ Fed. REg. 8240 (1954). 
It would seem desirable to have the very broad generalization of the proposed Regulations incorporated in the Code itself in order to insure proper authorization for the rule. ${ }^{43}$

\section{"Redemption" Defined}

The old Section $115(\mathrm{~g})$ of the 1939 Code literally applied only where a corporation "cancelled" or "redeemed" its stock. This gave rise to considerable divergence of views in the decided cases as to whether the provision could apply where the corporation purchased its stock from its shareholders and held it as treasury stock without technically cancelling or redeeming it from a corporate law standpoint. ${ }^{44}$

The new Code sets this problem at rest by using the terms "redeem" and "redemption" in Section 302 and providing in Section 317 (b) as follows:

"For purposes of this part, stock shall be treated as redeemed by a corporation if the corporation acquires its stock from a shareholder in exchange for property, whether or not the stock so acquired is cancelled, retired, or held as treasury stock."

The House bill provided that "a distribution of property accompanying a reduction in the par or stated value of stock shall be treated to the extent of the amount of such a reduction as a distribution in redemption of stock." 45 The Senate eliminated the provision with the statement in the Finance Committee Report that "no inference is to be drawn by the elimination of this provision in your committee's bill as to the status of existing law in this area." 46 The proposed Regulations have included language along the lines of the House bill. They state:

"For purposes of this subchapter, if a corporation makes a distribution of property accompanying a reduction in the par or stated value of its outstanding stock, the amount distributed shall be treated as received in a redemption of stock." 47

This statement should end the doubt on this point which has existed for some time and should eliminate the need for actually turning in

43. Perhaps the broad generalization of Code $\$ 1016(a)(1)$ relating to adjustments to basis of property furnish some foundation for the rule in the proposed Regulations.

44. Compare Kirschenbaum v. Commissioner, 155 F.2d 23 (2d Cir. 1946), with Alpers v. Commissioner, 126 F.2d 58 (2d Cir. 1942), and Commissioner v. Snite, 177 F.2d 819 (7th Cir. 1949).

45. H.R. 8300, 83d Cong., 2d Sess. $\$ 312(\mathrm{e})$ (1954).

46. SEN. REP. 252.

47. U.S. Treas. Proposed Reg. §1.317-2, 19 FED. REg. 8254 (1954). 
shares where a reduction in par or stated value presents fewer practical problems from a corporate law standpoint.

\section{Constructive Ownership of Stock-Section 318}

Some of the principal difficulties under the new Subchapter C, and particularly under the provisions of Section 302, flow from the socalled "attribution" or "constructive stock ownership" rules found in Section 318. Somewhat comparable rules have existed for many years in the provisions relating to personal holding companies ${ }^{48}$ and foreign personal holding companies, ${ }^{49}$ and also in connection with the disallowance of losses and expenses in transactions between related taxpayers. $^{\text {50 }}$ But until the 1954 Code there were no specific provisions for attribution of stock ownership in connection with the determination of whether stock redemptions are disproportionate for purposes of determining essential equivalence to a dividend. Several years ago the Bureau of Internal Revenue proposed to amend the old Regulations under Section $115(\mathrm{~g})$ to provide in effect that for such purposes an individual would be considered to own the stock owned by closely related members of his family. ${ }^{51}$ After the amendment had been in proposal form for a considerable time, it was withdrawn by the Treasury Department. ${ }^{52}$

\section{Application of the Rules to Section 302(b)(1)}

The new statutory attribution rules in Section 318 provide in this area an element of certainty heretofore lacking, but, as is so often the case, certainty is accompanied by rigidity and some inequity. This might not create such a difficult problem if the rules of Section 318 apply only in determining whether under the specific tests of Section 302 (b) (2) and (3) the redemption is substantially disproportionate or represents a termination of the shareholder's interest. But the proposed Regulations apparently take the position that the attribution rules apply as well under Section 302 (b) (1) in determining whether the distribution is "essentially equivalent to a dividend." The Regulations, after stating that pro rata redemptions will ordinarily be con$\S 544)$.

48. Int. Rev. Code of 1939, §503, 52 Stat. 559 (now Int. Rev. Code of 1954, $\S 554)$.

49. Int. Rev. Code of 1939, §333, 52 Stat. 547 (now INT. Rev. Code of 1954,

50. Int. Rev. Code of 1939, $\$ 24$ (b) (2), 52 Stat. 464 (now INT. Rev. Code of 1954, §267(c)).

51. Proposed Amendment to U.S. TrEas. Reg. 111, §29.115-9 (1946), 16 FeD. REg. 10312 (1951).

52. See 5 CCH 1953 Stand. Fed. Tax Rep. 43,002. 
sidered essentially equivalent to a dividend, contain the following comment:

"In all other cases (except those described in section 302 (b) (2), (3), and (4)), the question whether a distribution is essentially equivalent to a dividend depends upon the circumstances of each case. In such cases, the facts and circumstances should be reported to the Commissioner for his determination. Except as otherwise provided in section 302(c)(2) (relating to the determination of ozenership of stock), the provisions of section $318(a)$ (relating to constructive ownership) are applicable." ${ }^{53}$

In the Code itself Section 318 commences with the words "For the purposes of those provisions of this subchapter to which the rules contained in this section are expressly made applicable." 54 Section 302 (c) (1) states that ". . . Section 318(a) shall apply in determining the ownership of stock for purposes of this section." The words "ownership" and "owned" are found only in Section 302(b) (2) and (3) and are not found in Section 302(b)(1) dealing broadly with redemptions "not essentially equivalent to a dividend." As a matter of strict statutory construction, therefore, it can well be argued that the rules of Section 318 do not apply for the latter purpose. This can be buttressed by statements in the Senate Finance Committee Report that by inserting Section 302(b) (1) the Committee "follows existing law." 55 But beyond that, it would seem that as a policy matter the proposed Regulations should be changed in order to make clear that there is a safety valve permitting the issuance of rulings in situations where the strict attribution rules operate in an obviously unfair and inequitable fashion. ${ }^{56}$ The Senate apparently intended to provide that very mechanism where the new specific rules do not operate fairly in the stock redemption field. It is to be hoped that in the final Regulations the Treasury will clarify its position on this issue. added).

53. U.S. Treas. Proposed Reg. §1.302-2(b), 19 FED. REG. 8239 (1954) (italics

54. $\$ 318(\mathrm{a})$ (italics added).

55. SeN. REP. 44. Note that in other sentences the Committee states that it "intends to revert in part to existing law." See also text at note 12 supra.

56. Assume two persons are the sole residuary beneficiaries in equal shares of an estate and are the sole owners in equal shares of all stock of a corporation. They have a bona fide dispute between themselves and one of them is bought out entirely by the corporation and severs all connection with the company. Nevertheless, it is impossible at this point to wind up completely the estate of which they are equal co-beneficiaries. Apparently the person bought out cannot qualify for capital gains treatment under $\$ 302$ (b) (2) or (3) because he is still deemed to be the owner of $50 \%$ of the stock of the corporation so long as he remains the beneficiary of the estate in equal shares. See text following note 62 infra. 


\section{The Specific Attribution Rules}

Section 318 provides rules for attributing to the taxpayer stock owned under certain conditions by members of his family. It also provides for attributing stock ownership between a partnership and its partners, an estate and its beneficiaries, a trust and its benieficiaries, a corporation and its shareholders; and it contains special rules relating to stock subject to options.

Members of a Family.-Section 318(a) (1) states in general that an individual shall be considered as owning the stock owned, directly or indirectly, by or for his spouse, his children, grandchildren and parents. This rule is comparable generally to that which has long existed for personal holding company tax purposes, but there are several significant changes:

(1) stock owned by a spouse is not attributed to the taxpayer if the spouse is "legally separated from the taxpayer under a decree of divorce or separate maintenance";

(2) brothers and sisters are not included within the attribution group;

(3) while all ancestors are included for personal holding company tax purposes, parents are the only ancestors who are included under Section 318; grandparents and great-grandparents are not included; and

(4) while all "lineal descendants" are included for personal holding company tax purposes, children and grandchildren are the only descendants included under Section 318; great-grandchildren would not be included under Section 318 .

The proposed Regulations ${ }^{57}$ contain the following illustration of the application of the family rule:

$\begin{array}{lcc} & \begin{array}{c}\text { Shares } \\ \text { Actually Owned }\end{array} & \begin{array}{c}\text { Total Shares } \\ \text { Deemed Owned }\end{array} \\ H & 25 & 100 \\ W \text { (H's Wife) } & 25 & 100 \\ S \text { (H's Son) } & 25 & 100 \\ G \text { (S's Son) } & 25 & 50 \\ \text { Total Shares Outstanding } & 100 & \end{array}$

Under this illustration $H, W$ and $S$ are each considered to own all of the outstanding stock of the company under Section 318 and $G$

57. U.S. Treas. Proposed Reg. §1.318-2(a), 19 FED. REg. 8255 (1954). 
is considered to own one-half of the outstanding shares. $H$ is treated as owning the stock owned by himself, his wife, his son and his grandson. $W$ is treated as owning all the stock owned by her husband, her son and her grandson. $S$ is treated as owning the stock owned by his father, his mother and his son. $G$ is treated as owning the stock actually owned by himself and his father, but is not treated as owning the stock owned by his two grandparents. Though $G$ is treated as owning all stock owned by his father and his father is treated as owning the stock owned by his parents, it is specifically provided in the statute and the proposed Regulations that the stock of the grandparents attributed to the father is not again attributed to the son. ${ }^{58}$ However, as will be noted below, two-step attribution is prohibited only under the "family" rule; under all other rules of Section 318 stock considered constructively owned by a person is treated as actually owned by him for purposes of attributing such ownership to other persons. ${ }^{59}$

In the above illustration none of the stock owned by $H, W$ or $S$ could be redeemed under the substantially disproportionate rule since each would still constructively own all the outstanding stock after the redemption. But if at least 17 of $G$ 's 25 shares were redeemed, his percentage ownership, actual and constructive, would drop below $80 \%$ of his former ownership and he would receive capital gain treatment.

Partnerships.-Section 318(a) (2) (A) provides that stock owned, directly or indirectly, by or for a partnership shall be considered as being owned proportionately by its partners; and further, that stock owned, directly or indirectly, by or for a partner shall be considered as being owned by the partnership. Under the personal holding company tax provisions, stock owned by a partnership is deemed to be proportionately owned by the partners; and each partner is deemed to own the stock owned by his partners. ${ }^{60}$ In the personal holding company situation there is no need to attribute to the partnership stock owned by the partners since the inquiry there is related solely to the beneficial ownership of corporate stock by individuals.

The proposed Regulations under Section 318 illustrate the operation of the partnership attribution rule as follows: ${ }^{61}$ (1954).

58. §318(a) (4) (B); U.S. Treas. Proposed Reg. §1.318-4, 19 Fed. Reg. 8255

59. §318(a) (4) (A); U.S. Treas. Proposed Reg. \$1.318-3(a), 19 Fed. Reg. 8255 (1954).

60. $\$ 544(a)(1),(2)$. (1954).

61. U.S. Treas. Proposed Reg. §1.318-2(b), Example (1), 19 Fed. REG. 8255 


\begin{tabular}{|c|c|c|}
\hline & $\begin{array}{c}\text { Shares } \\
\text { Actually Owned }\end{array}$ & $\begin{array}{l}\text { Total Shares } \\
\text { Deemed Owned }\end{array}$ \\
\hline$A$ & 50 & 75 \\
\hline $\begin{array}{l}\text { Partnership in which } A \\
\text { has a } 50 \% \text { interest }\end{array}$ & 50 & 100 \\
\hline Total Outstanding S & res 100 & \\
\hline
\end{tabular}

Partner $A$ is treated as owning 75 shares, consisting of the 50 shares owned by him individually and one-half of the 50 shares owned by the partnership in which he has a $50 \%$ interest. The partnership is treated as owning all of the outstanding stock of the corporation because there is attributed to the partnership all stock owned by any partners, regardless of how small their interest is in the partnership. Thus in this illustration it is not possible to redeem any of the stock owned by the partnership at a capital gain under Section 302(b) (2) or (3) if $A$ remains as a partner, because after the redemption the partnership would still be deemed to own all of the outstanding stock of the corporation. Nor is it possible to redeem at capital gain rates under Section 302 (b) (2) or (3) any of the stock owned by $A$ so long as he has a $50 \%$ interest in the partnership, because even if all of his stock is redeemed and the only remaining stock is that owned by the partnership, he will thereafter still be deemed to own one-half of the outstanding stock of the corporation; he cannot then comply with the requirement of Section 302 (b) (2) (B) that after the redemption he must own less than 50\% of the voting stock. However, if $A$ would simultaneously withdraw from the partnership, it would seem that his stock could be redeemed at capital gain rates. Thus in a situation where there is a general buy-sell agreement between several persons who are both partners in a partnership and co-stockholders in a corporation, if the agreement operates simultaneously with respect to both the partnership and the corporations on death or withdrawal of any individual, the partnership attribution rules should not apply to the stock redemption.

The illustration in the Regulations makes no comment as to how much stock would be considered owned by $B$, the remaining partner, who actually owns no stock of the corporation but has a $50 \%$ interest in the partnership. It is clear that he is regarded as owning at least 25 shares, being one-half of those actually owned by the partnership. But is he to be regarded as owning in addition any part of the shares actually owned by his partner $A$ ? Unlike the personal holding company provisions mentioned above, Section 318 does not require at- 
tribution between partners as such. From this it might have been expected that $B$ would not be deemed to own any of the stock actually owned by $A$. But under Section 318 it is clear that the partnership is regarded as owning all of the 50 shares owned by $A$; and Section 318 (a) (4) provides that with the sole exception of attribution within a family group, stock constructively owned by a person under Section 318 shall for purposes of Section 318 be treated as actually owned by such person. Hence as a matter of literal statutory interpretation, it appears that $B$ will be regarded as owning 50 shares, consisting of (a) one-half of the 50 shares actually owned by the partnership and (b) one-half of the additional 50 shares constructively owned by the partnership by virtue of $A$ 's ownership. The proposed Regulations take this position in another example. ${ }^{62}$

Estates.-The rules relating to estates and their beneficiaries are identical with those relating to partnerships and partners. Stock owned, directly or indirectly, by or for an estate is considered as being owned proportionately by its beneficiaries; and stock owned, directly or indirectly, by or for a beneficiary of an estate is considered as being owned by the estate. ${ }^{63}$ The first part of the rule, relating to attribution to a beneficiary of stock owned by an estate, is similar to that existing in the personal holding company field ; ${ }^{64}$ yet for personal holding company tax purposes there has never been attribution between co-beneficiaries.

In the proposed Regulations the operation of this provision is illustrated as follows: ${ }^{65}$

Decedent's Estate in which

$\begin{array}{cc}\text { Shares } & \text { Total Shares } \\ \text { Actually } & \text { Considered } \\ \text { Owned } & \text { Owned }\end{array}$

$A$ has $50 \%$ interest in fee,

$B$ has life estate in $50 \%$,

$C$ has remainder interest

$\begin{array}{lll}\text { in } 50 \% & 50 & 80 \\ A & 12 & 46 \\ B & 18 & 49 \\ C & 20 & 20\end{array}$

Total Outstanding Shares 100

62. U.S. Treas. Proposed Reg. $§ 1.318-3(c)$, Example (3), 19 FED. REG. 8255 (1954).

63. $\$ 318(2)(2)(A)$.

64. §544(a) (1). (1954).

65. U.S. Treas. Proposed Reg. \$1.318-2(b), Example 5, 19 FED. REG. 8255 
In this illustration the estate is considered as owning (a) the 50 shares which it actually owns, (b) the 12 shares owned by $A$, who has a $50 \%$ interest in the fee, and (c) the 18 shares owned by $B$, who has a life estate in the remaining $50 \%$ of the estate. The estate is not considered to own the stock owned by $C$, the Regulations taking the position that he is not considered a beneficiary of the estate under Section 318 since he has no direct present interest in the income produced by the property held by the estate. ${ }^{66}$

Beneficiary $A$ is regarded as owning (a) the 12 shares he actually owns, (b) one-half of the 50 shares owned by the estate and (c) onehalf of the 18 shares actually owned by beneficiary $B$ but considered constructively owned by the estate under Section 318 .

Beneficiary $B$ is regarded as owning (a) the 18 shares which he actually owns, (b) one-half of the 50 shares owned by the estate (even though he has only a life interest in those shares), and (c) onehalf of the 12 shares actually owned by $A$ but considered constructively owned by the estate.

The practical result in this illustration is that none of the stock owned by the estate can be redeemed at capital gain rates under Section 302 (b) (2) or (3), since the estate would still be deemed to own the stock owned by $A$ and $B$ and their stock would constitute more than $50 \%$ of the total outstanding. ${ }^{.7}$ Nor would it be possible to redeem any of $A$ 's stock since even after the redemption of all of his stock he would still be deemed to own one-half of the estate's stock and onehalf of $B$ 's stock; as a result he could not bring his constructive ownership of stock below $80 \%$ of the percentage which he previously owned. ${ }^{68}$ But all of B's stock could be redeemed at capital gain rates because after the redemption he would be considered owning less than $50 \%$ of the outstanding stock and he would just manage to reduce his percentage ownership sufficiently. ${ }^{69}$ Five, or more, of $C$ 's twenty shares could be redeemed at capital gain rates because none of the other stock is attributed to him..$^{70}$

66. This conclusion is different from that which would result in the case of a trust, where there are specific rules laid down in the statute regarding the interests of income beneficiaries and remaindermen. See text at note 71 infra.

67. There would then be outstanding a total of 50 shares, of which $A$ and $B$ would own a total of 30 , or $60 \%$.

68. $A$ would be treated as owning 46 of 100 shares outstanding (or $46 \%$ ) before the redemption and 34 of 88 shares (or $38.6 \%$ ) afterwards. To qualify as substantially disproportionate $A$ 's constructive ownership would have to drop below $36.8 \%$ (i.e., $80 \%$ of the original $46 \%$ ).

69. $B$ would be treated as owning 49 of 100 shares outstanding (or $49 \%$ ) before the redemption and 31 of 82 shares (or $37.8 \%$ ) afterwards, which is less than $80 \%$ of the former $49 \%$ ownership $(39.2 \%)$.

70. If 5 shares are redeemed, $C$ would be treated as owning 20 of 100 shares outstanding (or $20 \%$ ) before the redemption and 15 of 95 shares (or 15.7\%) afterwards, which is less than $80 \%$ of the former $20 \%$ ownership (16\%). 
To take another illustration, suppose that $E$ and $F$ are brothers, each of whom has a $50 \%$ interest in the estate of their father. $E$ owns 95 shares of the stock of $X$ corporation and $F$ owns the remaining 5 shares. Thus none of the stock is owned by the estate. Since there is no attribution under Section 318 between brothers, one would think that F's five shares could be redeemed at capital gain rates. But in the light of the literal language of the statute and the position taken in the proposed Regulations, $F$ 's shares could not be redeemed at capital gain rates because afterwards his brother would own all of the outstanding stock and, by virtue of their equal $50 \%$ interest in their father's estate, $F$ would still be considered as owning one-half of the stock of the corporation. Presumably the result would be avoided if the estate administration were completed so that the two brothers were no longer co-beneficiaries; or if the entire interest of one of the brothers in the estate was terminated by distribution of his interest in full to him, even though the estate continued in administration.

Obviously this provision of the statute is in need of immediate repair, particularly if the attribution rules are to be considered applicable under the broad test of essential equivalence to a dividend.

Trusts.-Stock owned, directly or indirectly, by or for a trust is treated as owned by its beneficiaries in proportion to the actuarial interests of the beneficiaries in the trust. ${ }^{71}$ Stock owned by a beneficiary is treated as owned by the trust unless the beneficiary's interest in the trust is a "remote contingent interest." For this purpose a contingent interest is considered remote if, under the maximum exercise of a discretion by the trustee in favor of the beneficiary, the value of the interest computed actuarially is $5 \%$ or less of the value of the trust property.

The proposed Regulations illustrate the trust provisions as follows : ${ }^{\mathbf{2}}$

Shares Total Shares

Actually Owned Considered Owned

A 75

76

Testamentary trust in which $A$ has a vested remainder worth $4 \%$ actuarially

Total

100

71. $\S 318(a)(2)(B)$.

72. U.S. Treas. Proposed Reg. §1.318-2(b), Example 2, 19 FED. REG. 8255 (1954). 
Here $A$ is treated as owning, in addition to the stock actually owned by him, $4 \%$ of the 25 shares owned by the trust since his actuarial interest is $4 \%$. The trust is regarded as owning not only its own stock but also all of $A$ 's stock since he has a vested remainder. However, as the proposed Regulations also indicate, ${ }^{73}$ if $A$ has a contingent remainder rather than a vested remainder, then even though he still has a $4 \%$ actuarial interest, the trust will not be regarded as owning any of the stock actually owned by $A$ since his interest is both contingent and remote.

Here again there appears to be two-step attribution between cobeneficiaries of a trust, unless the actual owner of the stock has only a contingent interest in the trust worth less than $5 \%$ actuarially.

Since the attribution rules for estates differ from those applicable to trusts, it may be significant whether a redemption occurs while an estate is in administration or is deferred until a testamentary trust has been set up.

Corporations.-Section 318(a) (2) (C) provides:

"(C) Corporations.-If 50 percent or more in value of the stock in a corporation is owned, directly or indirectly, by or for any person, then-

(i) such person shall be considered as owning the stock owned, directly or indirectly, by or for that corporation, in that proportion which the value of the stock which such person so owns bears to the value of all the stock in such corporation; and

(ii) such corporation shall be considered as owning the stock owned, directly or indirectly, by or for that person."

The proposed Regulations illustrate the operation of this provision as follows: ${ }^{74}$

Corporation $O$ 's

Stockholders

$A$

$B$

Corporation $M$, Owned $70 \%$

by $A$ and $30 \%$ by $B$

$\begin{array}{cc}\text { Shares } & \text { Total Shares } \\ \text { Actually Owned } & \text { Considered Owned } \\ 50 & 85\end{array}$

0

50

100

\section{Total Shares Outstanding $\quad 100$}

Stockholder $A$ is regarded as owning not only his own stock but $70 \%$ of the 50 shares owned by Corporation $M$, giving him actual

73. Id., Example 3, 19 FED. REg. 8255 (1954). (1954).

74. U.S. Treas. Proposed Reg. §1.318-2(b), Example 4, 19 FED. REg. 8255 
and constructive ownership of 85 of the 100 shares outstanding. Stockholder $B$, who owns no stock himself, is not regarded as owning any stock constructively since he owns less than $50 \%$ of the stock of Corporation $M{ }^{75}$ Here none of the Corporation $O$ stock owned by Corporation $M$ could be redeemed at capital gain rates under Section 302 (b) (2) or (3) since it would be regarded as still owning $100 \%$ of the Corporation $O$ stock outstanding after the redemption, because of the attribution to it of all the stock owned by stockholder $A$. Nor could any of $A$ 's stock be redeemed at capital gain rates under Section 302 (b) (2) or (3) since through his ownership of $70 \%$ of Corporation $M$ he would own $70 \%$ or more of the Corporation $O$ stock even if all of his own holdings of Corporation $O$ stock were fully redeemed. But redemption of his stock interest in Corporation $O$ would be possible if he first reduced his interest in Corporation $M$ below $50 \%$.

It is to be noted that in determining whether a shareholder owns $50 \%$ or more of the stock of another corporation, the attribution rules are applicable. Thus if a shareholder actually owns $30 \%$ of the stock of Corporation $X$, and his parents own the balance of the $X$ stock, then the person will have attributed to him any stock in Corporation $Y$ which is owned by Corporation $X{ }^{76}$

Options.-Section 318 (a) (3) provides that if a person has an option to acquire stock, such stock will be considered as owned by him. Neither the statute nor the proposed Regulations state whether the person who gave the option is still treated as owning it for the purpose of determining his interest in the corporation. In the similar provision for personal holding company tax purposes, it is provided that the option rule shall be applied only where its effect is to make the company a personal holding company. Probably the statute here would be construed to reach the same result on the theory that the attribution of constructive ownership to the optionee does not affect the actual ownership of the optionor.

\section{Application of Section 346 to Stock Redemptions}

Section $331(a)(2)$ states that amounts distributed in partial liquidation, as defined in Section 346, shall be treated as in part or full

75. For certain purposes in $\$ 304$ (relating to redemption by related corporations) and $\S 382(a)(3)$ (relating to special limitations on net operating loss carry-overs), it is provided that attribution between corporations and stockholders shall be required even though the stockholder owns less than $50 \%$ in value of the stock of the corporation. The Regulations contain an example showing that for that limited purpose, a $30 \%$ shareholder of a corporation would be deemed to own his proportionate part of any stock which that corporation owned in another corporation. See U.S. Treas. Proposed Reg. §1.318-3(c), Example 5, 19 FED. REG. 8255 (1954).

76. Id. \$1.318-3(c), Example 4, 19 FED. REg. 8255 (1954). See also U.S. Treas. Proposed Reg. \$1.318-3(b) (3), 19 FEd. Reg. 8255 (1954). 
payment in exchange for the stock. Section 346 provides that the distribution shall be treated as in partial liquidation if it is one of a series of distributions in redemption of all the outstanding stock pursuant to a plan, or if the distribution

(a) is not essentially equivalent to a dividend,

(b) is in redemption of a part of the stock of the corporation pursuant to a plan, and

(c) occurs within the taxable year in which the plan is adopted or within the succeeding taxable year.

Section 346 (b) provides that a distribution shall be automatically treated as a partial liquidation if under certain prescribed conditions it is attributable to the termination of a business of the corporation. But both the statute and the proposed Regulations ${ }^{\mathbf{7 7}}$ state that a distribution can be a partial liquidation without complying with the specific requirements of $346(\mathrm{~b})$ concerning termination of a business. The Regulations cite as an illustration of this type of situation a case in which there is "a genuine contraction of the corporate business such as the distribution of unused insurance proceeds recovered as the result of a fire which destroyed part of the business causing a cessation of a part of its activities." 78 And the Senate Finance Committee Report, referring to the general definition of partial liquidation in Section 346 (a) states:

"Primarily, this definition involves the concept of 'corporate contraction' as developed under existing law." 79

Despite these statements in the proposed Regulations and in the Committee Report referring to contraction of the business as an element in the definition of partial liquidation, the statutory language itself does not require contraction of the business as a prerequisite. Assuming that the distribution is made pursuant to a plan, and occurs within the year of adoption of a plan or the following year, the distribution literally qualifies as a partial liquidation if it is not "essentially equivalent to a dividend." These words are identical with those contained in Section 302(b) (1).

It is important to note that the attribution rules of Section 318, which the proposed Regulations say apply under Section 302(b)(1), are not made applicable by the statute to Section 346 . Hence even

77. U.S. Treas. Proposed Reg. $\$ 1.346-1$ (a), 19 FED. REg. 8267 (1954).

78. See Joseph Imler, 11 T.C. 836 (1948).

79. SEN. REP. 262. 
if the Treasury should succeed in applying the statutory attribution rules to Section 302 (b) (1), it would still be faced with the assertion of capital gain treatment under Section 346(a) (2) even where there is no "contraction of the business" as such..$^{80}$

To meet such a contention the Commissioner would have to take the position either that the words "not essentially equivalent to a dividend" mean something different in Section 346(a)(2) than they do in Section 302(b) (1), or else that the words "pursuant to a plan" in Section 346 (a) (2) require some program for change in the business conducted by the corporation. Obviously there is doubt whether these statutory words can be construed in this manner, though some evidence of congressional intent to accomplish that result may be found in the general language of the Senate Finance Committee Report explaining that non-pro rata redemptions are dealt with in Part I and that "on the other hand, those distributions characterized by what happens solely at the corporate level . . . would be included as within the concept of a partial liquidation." 81 But if the Treasury intends to take this stand it should endeavor to make known its position with some firmness in the final Regulations, for at present the only suggestion lies in citing the facts of the Imler case ${ }^{82}$ in the Regulations as an "example" of a partial liquidation. ${ }^{83}$

\section{CONCLUSION}

The attempt to incorporate in the statute certain specific rules relating to stock redemptions has necessarily left a number of detailed questions of statutory construction. Preferably these should be set at rest by statutory amendment in the near future. Certainly some of the attribution rules of Section 318 require revision. The interrelationship of Sections 302 and 346 should also be clarified. But if Section 302 (b) (1) is properly used as a safety valve, and especially if the final Regulations make clear that the strict statutory attribution rules of Sec-

80. Technical support for such a position might lie in the fact that $\$ 346(\mathrm{~b})$ (dealing with the specific rules regarding termination of a business) contains a statement that whether or not a distribution meets its requirements shall be determined without regard to whether or not the distribution is pro rata with respect to all the shareholders of the corporation. The fact that this statement applies under $\$ 346(\mathrm{~b})$ and not under $\$ 346$ (a) tends to confirm that the disproportionate nature of the distribution is a factor to be taken into account under $\$ 346$ (a).

81. Sen. Rep. 49. See discussion in text at p. 740 sutpra.

82. Joseph Imler, 11 T.C. 836 (1948).

83. This matter could be of special significance not only in determining gain to the corporation under $\$ 311$ but also with respect to transactions under $\$ 306$, because $\$ 306(b)(2)$ relieves "section 306 stock" from dividend treatment on redemption if the redemption occurs in a partial liquidation. 
tion 318 do not necessarily apply under Section 302(b)(1), the technical difficulties under the specific provisions of the statute need not prove insurmountable. While much yet remains to be done, the airing of these problems incident to the preparation, interpretation and ultimately the amendment of the 1954 Code should produce in the long run a set of rules far more satisfactory and definitive than was possible under the vague generalities of the old statute. 


\title{
University of Pennsylvania Law Review
}

\author{
Formerly \\ American Law Register \\ FOUNDED 1852
}

Member, National Association of Law Reviews

BOARD OF EDITORS

JOSEPH V. REAPH, JR., Editor-in-Chief

ROBERT I. KENDALL, JR., Managing Editor

David J. Kaufman, Note Editor Joel C. Coleman, Case Editor

HENRY S. Ruth, JR., Note Editor James M. Richardson, Case Editor

MERVIN M. WILF, Article Editor

JACr VAN BAALEN. Research Editor and Book Revieze Editor

RoBert M. BeCKMAN

W. Thomas Berriman

JoHN L. BoyLe

Matthew J. Broderick

Walter J. Colitns, JR.

Thomas A. EvErLy, Jr.

Stephen M. Feldman

Henry B. FitzPatrick, Jr.

Riceard H. Floum

Paul D. Guth

David C. Harrison

J. BARTON Harrison

Richard S. HofFMaNN

Dolores Korasan
ARthur W. Leibold, JR.

Peter J. Liacouras

Richard L. McMahon

Grorge J. MIILER

ARTHUR H. Moss

HarRis OMinsky

CuRTIS R. REITZ

S. WhITE RhYNe, JR.

ALAN M. RUBEN

CARL W. SchNEIDER

Albert S. Shaw, Jr.

William F. Sulitvan, Jr.

Alfred T. Wirtifams, Jr.

GUYLA F. WOODWARd

Edward W. Brennan, EsQ., Business Manager

Correspondence should be directed to departmental editors. 